\title{
The Implementation of Multicultural Education in History Learning at SMAN 3 Surakarta
}

\author{
Yusuf Perdana $^{* 1}$; Djono ${ }^{1}$; Suryo Ediyono ${ }^{2}$ \\ ${ }^{1}$ Faculty of Teacher Training and Education, Sebelas Maret University, Indonesia \\ ${ }^{2}$ Faculty of Cultural Sciences, Sebelas Maret University, Indonesia \\ Email: yusufperdana116@gmail.com
}

http://dx.doi.org/10.18415/ijmmu.v5i3.135

\begin{abstract}
The rise of issues related to multicultural issues such as tribal wars, separatism and other movements that have the potential to cause national disintegration are urgent and require appropriate solutions. In the Indonesian context, the younger generation (student) becomes a potential subject to break the multicultural conflict. In relation to the issue, one potential form of solution is multicultural education especially through historical learning because of its potential to build a sense of tolerance and mutual respect. Therefore, this article will focus on the discussion of the implementation of multicultural education in history learning at SMAN 3 Surakarta. The methodology used is the Case Study with the design of Robert K. Yin. The results of the study indicate that the strategies used by history teachers in applying multicultural education in learning history is Cooperative Learning with the form of discussion, group work and presentation. The strategy is considered suitable because it is able to figure out the Affective, Cognitive and Psychomotor aspects of students. Obstacles experienced are very diverse include student saturation, dissatisfaction with the group of teachers to the limitations of the cost of learning outside the classroom in the historical site observation activities that match historical learning materials so that the majority of learning done in the class using photo and video media.
\end{abstract}

Keywords: Implementation; Multicultural education; History learning

\section{Introduction}

Indonesia as a country whose society is composed of various tribes, races, customs, groups, groups and religions, as well as social strata. These conditions and situations are reasonable as long as this distinction is known. However, when such differences emerge and become a threat to harmony, the difference becomes a problem to be solved (Yaya Suryana and H. A. Rusdiana., 2015: 1).

On the other hand, Indonesia is one of the largest multicultural countries in the world. The truth of this statement can be seen from the wide and varied sociocultural and geographic conditions. Currently, the number of islands in the territory of the State of the Republic of Indonesia (NKRI) is about 13,000 large and small islands. The number of its population is more than 200 million people, consisting 
of 300 tribes using almost 200 different languages. In addition they also embrace different religions and beliefs such as Islam, Catholicism, Protestant Christianity, Hinduism, Buddhism, Confucianism and various beliefs (Yaqin., 2005: 3-4).

Yaqin (2005: 4) says that the diversity of these cultures, admittedly or not, will be able to cause the problems that are now facing this nation. Thuggery, Poverty, Violence, Separatism, Environmental Destruction and The loss of a sense of humanity to always respect the rights of others, is a tangible form as part of a multicultural. This indicates that with multicultural background conditions are very vulnerable to cause potential problems of SARA, Disintegration of the nation, and so forth. In line with the above statement, Suryana and Rusdiana (2015) stated that multicultural society, multiracial, and multi-religious communities have great potential for conflict between racial, religious and ethnic groups.

The existence of various diversity in Indonesia can trigger conflict between tribes, religion, race and culture. According to Salim in his journal entitled "Building Integration of the Nation" said that looting of shops, killing and non-indigenous rape in May 1998 in Jakarta contains features of social conflict between races, followed by church burnings (ketapang incident, Jakarta) and burning of mosques in Kupang, East Nusa Tenggara shows inter-religious social conflict, fights with inter-ethnic killings in Sambas, West Kalimantan reflects inter-ethnic conflicts, inter-religious and ethnic fights splicing together in Ambon, Maluku which spawned a minority conflict, Aceh and Riau civilian suits against the central government inter-regional and central conflicts and gunfire in East Timor signaled social conflict between political groups. This event is an impact of mutual understanding and disharmony in intercultural communication in a plural society (Salim., 1999: 50). Rustopo (2007: 2) argues that the events of May 1998 riots became a very frightening specter for Chinese ethnic communities in Surakarta City, whose homes, shops, businesses were vandalized, looted and burned by rioters. The value of the physical losses that most of the Chinese people carry to billions of rupiah.

The number of potential problems arising from multicultural background in a country so it is necessary a solution that is through education that is applied in the realm of the School of multicultural education. John Locke describes that education is a process of helping students who are considered empty, who can be filled with whatever the educator desires, also considered an immature, mature person who needs help to get out of ignorance. (U.H. Saidah., 2016: 5). Musa Asya'rie quoted (Yaya \& Rusdiana., 2015: 197) declared multicultural education meaningful as a way of life education process of respect, sincerity, tolerance to cultural diversity living in the midst of plural society so that learners will have the suppleness and mental flexibility of the nation in addressing social conflicts in society.

Education is one of the effective medium to give birth to a generation that has a view that can make diversity as a part that must be appreciated constructively. Because education is systemic, with the level of spread is quite evenly. Educational institutions of various levels that have spread widely in various parts of Indonesia. Therefore, education is a sufficiently effective means to achieve that ideal goal (Naim and Sauqi., 2008: 5).

Today's national education in Indonesia offered is multicultural education as a substitute for monocultural education, it is considered very appropriate. This means that Indonesia's current education is not only focused on a particular culture for the representation of the whole plural society, but its application is comprehensive and universal as supporting the implementation of democratic values to the service of all layers of Indonesian society in various aspects of life including education aspect. In line with this, it is said by Mahfud that multicultural education developed in Indonesia is in line with the development of democracy which is run in line with the policy of decentralization and regional autonomy (Mahfud., 2006: 7). 
James Banks defines multicultural education as a set of beliefs and explanations that recognize and value the importance of cultural and ethnic diversity in the form of lifestyle, social experience, personal identity, educational opportunities of individuals, groups or a State. He defines multicultural education as an idea, movement, educational reform, and educational process whose primary purpose is to change the structure of educational institutions so that male and female students, special needs students, and students who are members of various racial, ethnic and cultural groups, sorts have equal opportunities to achieve academic achievement in school (Yaya Suryana and H. A. Rusdiana., 2015: 196).

Multicultural education is a relatively new phenomenon in education. Before World War II it could be said that multicultural education is unknown. Even education is used as a political tool to exert power that monopolizes the educational system for a particular group. In other words, multicultural education is a new phenomenon in the intercourse of human beings who aspire for equal rights, including the right to equal education for all. "Education for All" (H.A.R Tilaar., 2004: 123).

The application of multicultural education in schools has a very precise position to prevent friction between different groups in Indonesia. The application of multicultural education is expected to shape the character and the multicultural character of the child from an early age. Iis Arifudin (2007 journal "Urgency Implementation of Multicultural Education at School") says that in schools should be instilled togetherness values, tolerant, and able to adjust in various differences. The educational process in this direction can be pursued by multicultural education. Multicultural education is a process of cultivating a respectful, sincere, and tolerant way of living to the diversity of cultures that live in a plural society.

An example is a school in Malaysia that implements multicultural education, multicultural school leaders, or schools aimed at multicultural education, should value diversity by articulating a culturally proficient vision for the site, assessing the culture of the site, managing the dynamics of difference by providing training systems and support for conflict resolution, institutionalizing cultural knowledge by modeling and monitoring school-wide and classroom practices, and adapting to diversity by assessing and changing current practices (Suseela Malakolunthua, Procedia Social and Behavior., 9: 2010).

Expected from the school system in Indonesia on the application of multicultural education will bring a change to the younger generation of early age by forming characters and characters that uphold the value of tolerance. As Rini Hartati S. (2013: 602) states in his work entitled "Implementation of Multicultural Education as a social capital in the life of the nation" which says that the expected effect of the implementation of multicultural education is the understanding and even awareness associated with the condition of a plural nation. So that awareness of multiculturalism can be made as social capital in creating social interaction of society which is constructive for this nation.

\section{Methodology}

The method used in this research is qualitative method of Case Study with Robert K.Yin Design. Robert says the Case Study is one of the methods of social sciences research. Case studies are preferred to track contemporary events, when relevant events can not be manipulated. The case study therefore bases itself on techniques similar to the prevalence of historical strategy, but by adding two sources of evidence that are not usually included in the historian's choice of systematic observation and interview. Again, although case and historical studies may overlap, the unique strength of the case study is its ability to relate fully to the various types of documentary evidence. (Robert K. Yin., 2000: 1-12). 


\section{Discussion \\ The History Teacher's Strategy in Applying Multicultural Education}

Strategy is an important stage that history teachers do in applying multicultural education. The application of multicultural education can be achieved optimally if it has a good strategy. Every teacher must have different strategies in applying multicultural education in history learning. Implementation of multicultural education in an educational institution is very important and should be integrated into the subjects especially history subjects, because institutions have great potential in instilling multicultural education in learners. Thus, the teacher is an important component in a learning that must have a good strategy about multicultural education.

SMA Negeri 3 Surakarta is a public education institution in Surakarta city which is very potential in developing and integrating multicultural education. This is evident from the background of schools whose students are very diverse ranging from the religion of Islam, Christianity, Catholicism, Hinduism and Buddhism. Both of ethnic Javanese, Arabic and Chinese. The culture of tolerance in SMAN 3 Surakarta is well underway, all the students blend in without coercion and discrimination. All this can not be separated from the role of teachers who apply multicultural education using a good strategy. To ensure the strategy of the history teacher in applying multicultural education then interviewed the teacher of history subject of Drs. Sri Widadi, M. Hum who said that:

One of the strategies used in applying multicultural education in learning history is through Cooperative Learning which involves all learners. So all are involved in the learning of history. The strategy is to apply the learning Model with group discussion. For example, we divide into five groups and discuss them with different materials, after the students are given the opportunity to communicate the results of the discussion with the presentation in front of the other group. Thus later the children can convey what is discussed with the group. At the end of the presentation, the students are given chances to answer questions and responses from other groups. Some questions or refutations are accommodated and then are answered by the group of presentations. It is a strategy in applying multicultural education through Cooperative Learning.

The above statement is in line with the teacher of Dra's mother history. Puji Rahayu stating that:

Strategies in applying multicultural education in various historical learning, but all that must be in accordance with the material. Because we conceptualize the material first by providing the media in accordance with the material. Strategy can not be separated from group discussions by dividing group members according to the teacher so that there is no discrimination and random so that all students can mingle. Random selection for example by counting according to serial number. So it is expected of this system all children can mingle so as not to cause groups that restrict students to know each other.

In addition students are also given examples of past events and my life experience, so that students can take positive aspects, meyikapinya and see the response of children. For example giving an incident about the less fortunate then how the student response and how to look at the student whether empathy to another group and whether it is tolerated, it can all be seen with examples of events that we gave earlier as well as teachers also provide the best direction either done students.

The above statement is in line with the storytelling of the teacher of the history of mother Dyah Retnaningsih, S.Pd who stated that: 
The strategy used for high school children in applying multicultural education in learning history is Coopertive Learning with discussion, group work, learning model by adjusting the material. For example in class $\mathrm{X}$ there is material tools and culture of pre-era letters ie there is megalithic, neolithic, mesolitikum and paleolitikum. Then formed a group and each group is given a different image with other groups .. In addition there is a presentation that is about the various cultures multicultural since pre-literacy. Through this strategy is expected to provide an understanding of respecting other cultures, how students tolerate, empathy and so forth.

On the statement of the first teacher of history it can be explained that the history teacher's strategy of applying multicultural education through Cooperative Learning. With the method of discussion is expected students can communicate with other students and appreciate the differences of opinion of other students. can solve material-related problems with good discussion and tolerance among students, as well as to promote equality of rights and views for all students. Furthermore, according to a second history teacher statement can be explained that the strategy of history teachers in applying multicultural education is using group discussion as a good strategy in applying multicultural education.

Division of groups by teacher because to avoid discrimination or groups that restrict students. That way students are expected to blend in with each other. In addition, teacher strategies also use past events as well as the life experience of the history teacher itself. So it is expected from these events the student can take positive side. While the third history teacher statement is using Coopertive Learning strategy because it can see various sides ranging from affective, cognitive to psychomotor students. Thus, group work can eliminate the boundaries of students and require all students to blend, tolerate and appreciate other student disagreements and provide equal opportunities to all students during the presentation sessions.

So it can be concluded that the history teacher's strategy in applying multicultural education is diverse, but Cooperative Learning remains a priority in applying multicultural education, because with the method of discussion, group work and presentation will produce some aspects such as affective, cognitive and psychomotor. And can see the high sense of tolerance, empathy to communication between students. Azra explained that multicultural education as a substitute for intercultural education is expected to cultivate a caring and understanding attitude or a politic, recognition of the culture of human groups, such as tolerance, ethnocultural and religious differences, discrimination, human rights, democracy and plurality, universal humanity, and subjects other relevant (Suryana \& Rusdiana., 2015: 197).

\section{The Obstacles Faced by History Teacher in Applying Multicultural Education in History Learning}

The implementation of multicultural education in schools conducted by history teachers certainly can not be separated from obstacles. However, these constraints are not a significant obstacle in teaching and learning activities, but as a driver of history teachers in performing their duties as a good history teacher.

The following is the statement of history teacher subject of Drs. Sri Widadi, M.Hum on the obstacles experienced in applying multicultural education in history learning:

The obstacles in applying multicultural education in the learning of history do exist. If the morning time is indeed the constraint can be minimized but for the last hours the condition of children who vary seprti tired and sleepy then it makes less than optimal learning and it affects the final outcomes of students because students' understanding of the material less than the maximum. 
In line with the above statement, the obstacles in applying multicultural education in the history of learning are also experienced by the teacher of the history of Dra's mother. Praise Rahayu who said that:

Constraints in applying multicultural education are among the less suitable students in the selection of group members formed by teachers. So there are silent and less active in discussion.

This obstacle is different from the obstacles experienced by the teacher of history subjects Dyah Retnaningsih, S. Pd who said:

Constraints in applying multicultural education are less optimal students in the learning process, because it is limited to the use of photo and video media. Whereas in historical material many historical relics are more optimal again if the learning is done outside the classroom and directly observe on sites that are in line with historical material. These constraints are caused by the lack of budget provided by the school, so that students have not been maximized to observe the objects and historical sites.

The first teacher history statement explains that the process of Teaching and Learning Activities during the day is an obstacle, because the condition of tired and sleepy students also influence less optimal learning and impact on students 'final results due to students' understanding of less than optimal material. Furthermore, the second history teacher explained that obstacles experienced by history teachers in applying multicultural education are less suitable students understanding of group members formed by teachers, which result in the attitude of students who are silent and less active in learning. Johanes fiercely defines human beings who is as social beings are group creatures and unable to live alone (Suryana \& Rusdiana., 2015: 56). While the third history teacher statement explains that the constraint experienced by history teachers is the lack of budget from school for outside learning classes in the subjects of history. With the lack of budget, students are not yet optimal to observe directly to the object or historical sites but more learning in the classroom with photo and video media that make students' understanding of learning less than the maximum.

\section{The Solution to the Constraints Experienced by the History Teacher}

Solutions to various obstacles experienced by history teachers in applying multicultural education in learning history such as using a good method that can foster the spirit of students and provide rewards to students who understand about the material taught, so sleepy and tired students in the day will felt lost but turned into a spirit in following learning maximally.

Responding to students who are less satisfied with the selection of group members by the teacher is by providing an understanding to blend each other and see all the same as well as tolerate the opinions of other students. For the limited cost in the execution of learning outside the classroom can be overcome through contributions from students with the objective of relevant and close sites of the school so that the cost is not burdensome students. 


\section{Conclusion}

The strategy used by history teachers in applying multicultural education in historical learning is very diverse, but the most widely used by history teachers is the Cooperative Learning strategy with a discussion model, group work and presentations. With these various strategies teachers can see how the affective, cognitive and psychomotor aspects of students such as how students tolerate, how to see all students equally, empathy students, and appreciate differences of opinion from other students.

Obstacles experienced by history teachers in applying multicultural education in learning history are very diverse, such as in the afternoon, students experience fatigue, drowsiness, less satisfied with the selection of groups conducted by teachers to the limitations of the cost for outdoor learning activities so that the majority of learning history is done in classes using photo and video media rather than direct observation of historical sites relating to historical material. With the various constraints that existed it is expected some solutions can reduce the constraints. Some of these solutions are by giving rewards to keep students passionate, giving students understanding that all students have the same rights of mingling with all friends and expressing opinions and appreciating opinions of others. In the limitation of fees, it can use exclusion made by students with the purpose of the site and the closest historical objects of the school so that the exclusion does not burden the students.

\section{References}

Arifudin, Iis. (2007). Urgensi Implementasi Pendidikan Multikultural di Sekolah. Purwokerto: P3M STAIN. Jurnal Pemikiran Alternatif Pendidikan Insania. 12(2): 220-233.

Emil, Salim. (1999). Membangun Intergrasi Bangsa" dalam sejarah pemikiran, Rekonstruksi, Persepsi. Jakarta: MSI dan ANRI.

Mahfud, Choirul. (2006). Pendidikan Multikultural. Yogyakarta: Pustaka Pelajar.

Naim, N. dan Sauqi, A. (2010). Pendidikan Multikultural Konsep dan Aplikasi. Jogjakarta: Ar-Ruzz Media Grup.

Rini Hartati S. (2013). Implementasi Pendidikan Multikultural Sebagai Modal Sosial Dalam Kehidupan Berbangsa. dalam Memahami Kembali Indonesia. Yogyakarta: Ikatan Sosiologi Indonesia dan LabSosio Sosiologi Universitas Sebelas Maret.

Rustopo. (2007). Menjadi Jawa: Orang-orang tionghoa dan Kebudayaan Jawa di Surakarta 1895-1998. Yogyakarta: Ombak.

Saidah. U. H. (2016). Pengantar Pendidikan Telaah pendidikan secara global dan nasional. Depok: PT. Raja Grafindo Persada.

Suryana, Yaya \& Rusdiana H. A. (2015). Pendidikan Multikultural, Konsep-Prinsip-Implementasi. Bandung: Pustaka Setia.

Suseela Malakolunthua. (2010). Kepemimpinan Budaya Responsif Untuk Pendidikan Multikultural: Kasus "Visi Sekolah" di Malaysia. Procedia Sosial dan Ilmu Perilaku. 9. E-Journal Science Direct.

The Interview with history teacher at SMA 3 Surakarta Dra. Dyah Retnaningsih, S. Pd, $13^{\text {th }} 2017$. 
The Interview with history teacher at SMA 3 Surakarta Dra. Puji Rahayu on December, $13^{\text {th }} 2017$.

The Interview with history teacher at SMA 3 Surakarta Drs. Sri Widadi, M. Hum on December, $13^{\text {th }}$ 2017.

Tilaar, H. A. R. (2004). Multikulturalisme (Tantangan-tantangan global masa depan dalam transformasi Pendidikan Nasional). Jakarta: PT. Widiasarana Indonesia.

Yaqin, M. Ainul. (2005). Pendidikan multikultural: Cross-Cultural Understanding Untuk Demokrasi dan Keadilan. Yogyakarta: Pilar Media.

Yin, Robert K. (2000). Studi Kasus: Desain dan Metode. Jakarta: PT. Raja Grafindo Persada.

\section{Copyrights}

Copyright for this article is retained by the author(s), with first publication rights granted to the journal.

This is an open-access article distributed under the terms and conditions of the Creative Commons Attribution license (http://creativecommons.org/licenses/by/4.0/). 